\title{
Patterns of craniofacial variation and taxonomic diversity in the South African Cercopithecidae fossil record
}

\author{
Tesla A. Monson, Marianne F. Brasil, Dominic J. Stratford, and Leslea J. Hlusko
}

\begin{abstract}
The rich paleontological record of South Africa is central in our understanding of Plio-Pleistocene mammalian evolution due in large part to the number of crania recovered. Because of the difficulty of chronometric control in many of the cave systems from which these fossils derive, extinct Old World Monkeys (OWMs) are often employed as biochronological markers, making the taxonomic identification of these primate remains particularly relevant to pursuing broader evolutionary questions relating to human evolution and faunal diversity shifts. The taxonomic relationships for the OWM fossils are reconstructed through phylogenetic systematics that rely heavily on craniodental traits. These analytical methods assume that these characters are developmentally, functionally, and genetically independent. This assumption is increasingly being questioned by analyses of extant phenotypic datasets and genetics. We statistically explored cranial variation in South African fossil papionins $(n=99)$ to determine whether or not extinct taxa reflect the same phenotypic covariance structure as has been reported for extant OWMs. Our results show that many of the cranial measurements are statistically significantly correlated and fail to distinguish between species or even genera of fossil papionins despite distinguishing extant species. Overall, our results suggest that these extinct OWM taxa cannot be discriminated using craniofacial measurements alone, or that the taxonomic designations, as they currently stand, are confounded.
\end{abstract}

Tesla A. Monson. Department of Integrative Biology, University of California, Berkeley, 3040 Valley Life Sciences Building \#3140, Berkeley, CA 94720, USA. tesla.monson@berkeley.edu Marianne F. Brasil. Department of Integrative Biology, University of California, Berkeley; Human Evolution Research Center, 3040 Valley Life Sciences Building \#3140, Berkeley, CA 94720, USA. mbrasil@berkeley.edu Dominic J. Stratford. School of Geography, Archaeology and Environmental Studies, University of the Witwatersrand, 1 Jan Smuts Avenue, Braamfontein 2000, Johannesburg, South Africa.

Dominic.Stratford@wits.ac.za

Leslea J. Hlusko. Department of Integrative Biology, University of California, Berkeley; Human Evolution Research Center, 3040 Valley Life Sciences Building \#3140, Berkeley, CA 94720, USA. hlusko@berkeley.edu

Keywords: Old World Monkeys; Pleistocene; taxonomy; Papionini; morphology; phenotypic covariation Submission: 10 June 2016 Acceptance: 23 February 2017

Monson, Tesla A., Brasil, Marianne F., Stratford, Dominic J., and Hlusko, Leslea J. 2017. Patterns of craniofacial variation and taxonomic diversity in the South African Cercopithecidae fossil record. Palaeontologia Electronica 20.1.7A: 1-20 palaeo-electronica.org/content/2017/1762-fossil-owm-cranial-variation 


\section{INTRODUCTION}

The South African fossil record has played a central role in our understanding of terrestrial mammalian evolution in the Plio-Pleistocene (Vrba, 1985; McKee, 1996; Faith and Behrensmeyer, 2013), including human evolution (Dart, 1925; Clarke et al., 1970; Clarke and Tobias, 1995; Partridge et al., 2003; Granger et al., 2015). With the announcements of Australopithecus sediba (Berger et al., 2010) and Homo naledi (Berger et al., 2015) in recent years, the Plio-Pleistocene fossil record of the southern part of the African continent is likely to play an increasingly important role in our understanding of the finer details of how our own lineage's evolution unfolded. However, this more detailed level of investigation is complicated by sedimentary geology associated with karstic cave systems, which are particularly challenging for chronometric dating (e.g., Partridge et al., 2003; Partridge, 2005; Pickering and Kramers, 2010; Herries and Shaw, 2011; Granger et al., 2015). With this in mind, the comparative morphological analyses of the fossils recovered from these sites are particularly problematical and simultaneously essential. Better paleobiological interpretation of fossilized morphologies-such as for Old World Monkeys-will hopefully help circumvent the difficulties posed by fossil records such as those from South African karstic sites.

South African Old World Monkeys (OWMs) are also an ideal taxon through which to refine our understanding of the etiology of morphological variation for at least four reasons. First, because they fall outside of our Linnaean Family (Hominidae), scientists arguably have less of a vested interest in the taxonomic results. Second, given their evolutionary proximity to us, OWMs are a relevant evolutionary (Jolly, 2001) and biomedical model for humans (VandeBerg et al., 2009). Consequently, we have an increasingly good understanding of the genetic underpinnings of OWM skeletal variation (Havill et al., 2005; Sherwood et al., 2008a, 2008b; Koh et al., 2010; Roseman et al., 2010; Joganic et al., 2012; Hlusko, 2016; Hlusko et al., 2016). Third, there is an abundant Plio-Pleistocene fossil record (Jablonski, 2002). And lastly, this fossil record of OWMs has been used as a biochronological tool, bench-marking events in human evolution (Delson, 1984, 1988; Williams et al., 2007) and the evolution of other mammals (Vrba, 1975; Harris and White, 1979; Vrba, 1982; Turner, 1990; Behrensmeyer et al., 1997; Souron et al., 2013).

However, another key feature of the South African OWM fossil record that is less often appre- ciated is the reality of their taxonomy. Since the discovery of the first baboon fossil in South Africa (Haughton, 1925), the taxonomy of fossil OWMs in South Africa has been both convoluted and contentious. Many species, and even genera of OWMs, have been shifted from one group to another over the last century by various researchers (e.g., Freedman, 1957; Szalay and Delson, 1979; Jablonski, 2002; Heaton, 2006; Gilbert, 2007). Additionally, some genera (e.g., Gorgopithecus and Dinopithecus) include only a handful of specimens (see Jablonski, 2002; Jablonski and Frost, 2010). A good example of this continued taxonomic rearrangement is specimen UCMP 56653, collected by the UC Africa Expedition (1947-1948; Monson et al., 2015). Originally classified as Parapapio antiquus when accessioned in 1948, UCMP 56653 was published as Parapapio whitei by Freedman (1965). Gilbert (2007), 40 years later, removed UCMP 56653 from genus Parapapio and used it, along with several other fossils, as the basis for the erection of a new genus, Procercocebus (Gilbert, 2007). Taxonomic debate is far from settled, in part because many of the South African fossil papionins are quantitatively and qualitatively similar to extant Papio. A closer investigation into the biological underpinnings of their cranial variation promises to yield some clarity.

\section{Craniofacial Integration}

The cranium is essential in paleontological investigations because it is often well preserved, highly variable across many primate species, and highly reflective of dietary and behavioral adaptations (Ravosa and Profant, 2000). Traditionally, variation in the anatomical structure of the muzzle, orbits, palate, and cranial vault has been used to distinguish fossil OWM taxa (e.g., Broom, 1940; Freedman, 1965; Szalay and Delson, 1979; Jablonski, 2002). More recently, cladistic analyses of a large number of craniodental features have been employed to interpret evolutionary relationships, and subsequently, name new species and genera (e.g., Gilbert, 2007, 2013). These analyses rely on the assumption that the characters used are independent of each other and are thereby independent indicators of evolutionary history. However, research on many different mammals, including primates, has demonstrated a significant degree of shared genetic effects (i.e., pleiotropy) among craniofacial features (Cheverud, 1982, 1988, 1996; Hallgrímsson et al., 2004). In contrast to the discrete characters traditionally used by anatomists (e.g., Halim, 2008), developmental 
studies yield evidence for interrelated parts of the cranium and face relative to other aspects of the skull. These interrelated suites of traits are called modules (e.g., Marroig and Cheverud, 2001; Hallgrímsson et al., 2004; Singh et al., 2012). Modules of phenotypic correlation are underlain by shared genetic, developmental, and/or functional influences (Olson and Miller, 1958; Cheverud, 1996; Klingenberg, 2008), and tend to vary in structure between primate groups, even closely related ones (e.g., Marroig and Cheverud, 2001).

Quantitative genetics has helped illuminate our understanding of the genetic architecture that underlies continuously variable phenotypes of the vertebrate skeleton, including the cranium (e.g., Cheverud and Buikstra, 1981; Cheverud, 1982; Leamy et al., 1999; Hlusko, 2004; Sherwood et al., 2008a, 2008b; Roseman et al., 2010). The vertebrate cranium is comprised of three major developmental components: the splanchnocranium (comprising the jaws, hyoid, and middle ear bones) the chondrocranium (supporting the brain and sensory organs) and the dermatocranium (comprising the roof and sides of the cranium) (Kardong, 1995; Hildebrand and Goslow, 2001; Webster and Webster, 2013). There has been a considerable amount of research investigating mammalian cranial integration (e.g., Cheverud, 1982; Roseman et al., 2009; Lieberman, 2011) and how components of the cranium covary more tightly relative to other components to form developmental modules (see Rizk, 2012). In macaques, for example, phenotypic correlations are much higher in traits that are functionally and/or developmentally related, suggesting that those traits co-evolve as a module (e.g., Cheverud, 1982; Ackermann and Cheverud, 2004). Within this phenotypic context, the primate cranium is conceptualized as having three general regions that loosely reflect the developmental components from which they derive: the basicranium, neurocranium, and face (Lieberman, 2011).

Closely related anthropoid species and genera tend to share a similar pattern and magnitude of craniofacial integration (Mitteroecker and Bookstein, 2008; Ackermann, 2009; Singh et al., 2012; Singleton, 2012). Deviations from the broad patterns may reflect evolutionary pressures that uniquely define particular lineages (e.g., Marroig and Cheverud, 2001; Ackermann, 2005; Goswami and Polly, 2010; Roseman et al., 2011). A comprehensive study of integration across mammals found that humans had the lowest magnitude of integration of the 15 mammalian orders $(n=3644)$; the highest magnitude of cranial integration was reported for Papio, higher than any other primate (Porto et al., 2009). In papionins, smaller units of modularity and integration have been described within the basi- and neurocranial regions: cranial vault, orbit, cranial base, nasal, and oral (Ackermann and Cheverud, 2004).

All of the research mentioned above has focused on extant primates. As a complement, we conducted an exploratory study of phenotypic variation in fossil cercopithecids to discern whether there is a similarly high degree of integration in fossil OWM crania, and whether or not this integration is likely to impact interpretations of primate taxonomy in the South African fossil record.

\section{MATERIALS AND METHODS}

\section{Materials}

African OWMs are a diverse group of monkeys represented by both arboreal and terrestrial taxa, and with diets ranging from seeds and nuts to grasses, leaves, and even some invertebrates (Nowak, 1991; Jablonski and Frost, 2010). With the exception of a few colobines, the majority of fossil South African OWM taxa have been attributed to tribe Papionini (Jablonski, 2002; Jablonski and Frost, 2010). A large proportion of fossils recovered have been included in the extinct genus Parapapio, a group for which the eastern and South African fossil record extends back at least until the earliest Pliocene (Jablonski and Frost, 2010). Many researchers agree that Parapapio is likely the group ancestral to living baboons and potentially a few other groups (e.g., the mangabeys and mandrills; Jablonski and Frost, 2010).

As a genus, Parapapio is diagnosed by its short, rounded muzzle with limited to no fossae excavation, weak maxillary ridges, slight to absent anteorbital drop, and straight nasal profile, as well as on the basis of its postcanine dental size (e.g., Jones, 1937; Freedman, 1957; Eisenhart, 1974; Heaton, 2006; Jablonski and Frost, 2010). Papio is distinguished from Parapapio by overall larger size, elongated muzzle with significant fossae excavation and robust maxillary ridges, as well as a steep anteorbital drop (Freedman, 1957; Heaton, 2006; Jablonski and Frost, 2010). Other large and robust extinct papionin taxa include Gorgopithecus and Dinopithecus, although the genus level distinction of these two taxa is debated given the limited number of specimens referred to them, and that these specimens are often taphonomically distorted (Broom, 1937, 1940; Broom and Robinson, 1949; Freedman, 1957; Szalay and Delson, 1979; Del- 
son, 1984; Jablonski, 1994; Heaton, 2006; Jablonski and Frost, 2010). Gorgopithecus, in particular, has been questioned because the series of traits that diagnose the genus (e.g., anteorbital drop, short nasals, lack of maxillary ridges), are largely based on only a few fossils, including KA192, a severely distorted and superoinferiorly compressed specimen (e.g., Freedman, 1957). Procercocebus, diagnosed by a series of variable craniodental traits, such as anterior temporal line morphology, is also represented by a limited fossil record (Gilbert, 2007; Jablonski and Frost, 2010). Overall, Theropithecus is one of the most taxonomically distinct fossil South African papionins, with thick and crenulated enamel on the molar teeth, and a squared supraorbital torus (Delson, 1993; Jablonski, 2002; Jablonski and Frost, 2010).

We collected 17 standard cranial measurements from 99 original fossils representing family Cercopithecidae held in the collections of the Ditsong National Museum of Natural History in Pretoria, the Evolutionary Studies Institute at University of the Witwatersrand, and the University of California Museum of Paleontology (Table 1). Following the most commonly accepted taxonomic identifications (Jablonski, 2002; Williams et al., 2007; Jablonski and Frost, 2010), our sample includes seven genera and 15 species, as well as 17 specimens of uncertain affinity (Table 1). Five of these genera are represented in Figure 1, which shows some of the range of craniofacial variation encompassed by this sample. Only adult specimens were included in the analyses, defined by having fully erupted adult dentitions. One exception, SK554, a juvenile Dinopithecus with third molars not yet fully erupted, was included in the analyses because it is the most complete cranial specimen representing this taxon. With the exception of Cercopithecoides, a colobine, all of the fossil genera sampled for this study are papionins. For comparison, we collected the same 17 cranial measurements from 81 extant African papionins, spanning five genera and species (Table 2).

Chronometric dating of South African fossil deposits is notoriously difficult (e.g., Partridge, 2005; Herries and Adams, 2013; Granger et al., 2015). Consequently, the time depth represented collectively by these fossils is uncertain. Based on the most recently published dates, it is possible that this sample represents one to three million years of evolution (e.g., Delson, 1988; Pickering and Kramers, 2010; Herries and Shaw, 2011; Reynolds and Kibii, 2011; Stratford et al., 2014; Granger et al., 2015; Monson et al., 2015). All specimens were analyzed without regard to these uncertain geologic ages.

\section{Data Collection Methods}

The 17 cranial measurements capture variation in size and shape through linear distance (Table 3; Appendix 1). To avoid inter-observer error, a single observer (T.M.) took all measurements by hand using Mitutoyo digital calipers. To test intra-observer error, T.M. measured a subsample of specimens $(n=41)$ three times. Average intra-observer error did not exceed $5 \%$ for any of the cranial measurements.

In cases of damaged fossil specimens, measurements were estimated only if the missing landmark location could be predicted with a high degree of confidence. These estimations are noted in the raw data table provided (Appendix 2) and included in the analyses. In cases where the missing landmark location could be predicted only with a low degree of confidence, we collected the measurements and marked them in the raw data but did not include them in the analyses. Raw data for the extant specimens are reported in Appendix 3.

\section{Analytical Methods}

All statistical analyses were implemented in the $\mathrm{R}$ statistical program v3.1.2 ( $\mathrm{R}$ Core Team, 2016). Basic descriptive statistics for the cranial measurements were calculated using the describeBy function in psych (Revelle, 2015). Bivariate analyses were plotted using the ggplot function in ggplot2 (Wickham, 2009). We conducted principle components analyses (PCA) using the prcomp function (Venables and Ripley, 2002) to explore the multivariate spread of the data. Because only a few specimens are complete enough to permit the collection of all of the measurements $(n=12)$, we used subsets of raw measurements available on a larger number of the fossil specimens for two iterations of PCA. PCA results were visualized with ggplot2 (Wickham, 2009).

We then ran a MANOVA to compare means of all cranial traits across genera. Because of the large number of cranial traits relative to genera represented, we divided the 17 traits into two subsets to run the MANOVA, and we analyzed the fossil and extant samples separately. Further analyses directly comparing genera were performed using ANOVA.

The extensive body of work on allometry in primates has prioritized removing size variation in order to better investigate variation in shape (e.g., 
TABLE 1. Genera and species represented, repository information, sample sizes, and specimen numbers used in this study. U Wits: University of the Witwatersrand, Johannesburg, South Africa; UCMP: University of California Museum of Paleontology, Berkeley, California, USA; Ditsong: Ditsong National Museum of Natural History, Pretoria, South Africa. TM211 was originally described as Papio spelaeus (Broom, 1936). M3147 has also been published as P. h. robinsoni (Gilbert et al., 2015).

\begin{tabular}{|c|c|c|c|c|c|c|}
\hline Genus & Species & Repository & $\mathbf{N}$ & Specimen numbers & Site(s) & References \\
\hline \multirow[t]{4}{*}{ Cercopithecoides } & C. molletti & Ditsong & 1 & SK551 & Swartkrans & McKee et al. (2011) \\
\hline & C. williamsi & Ditsong & 3 & KA195, KB5241C, MP36 & $\begin{array}{c}\text { Kromdraii, } \\
\text { Makapansgat }\end{array}$ & $\begin{array}{l}\text { Szalay and Delson (1979), } \\
\text { McKee et al. (2011), } \\
\text { Geissler (2013) }\end{array}$ \\
\hline & & U Wits & 1 & STS394A & Sterkfontein & Geissler (2013) \\
\hline & & Total & 5 & & & \\
\hline \multirow[t]{2}{*}{ Dinopithecus } & D. ingens & Ditsong & 5 & $\begin{array}{l}\text { SK553, SK554, SK599, } \\
\text { SK600, SK604 }\end{array}$ & Swartkrans & Gilbert (2013) \\
\hline & & Total & 5 & & & \\
\hline \multirow[t]{2}{*}{ Gorgopithecus } & G. major & Ditsong & 3 & KA153, KA605, KA944 & Kromdraii & Gilbert (2013) \\
\hline & & Total & 3 & & & \\
\hline \multirow[t]{7}{*}{ Papio } & $P$. angusticeps & Ditsong & 5 & $\begin{array}{c}\text { Co100, C0101, CO102, } \\
\text { Co135A, KA194 }\end{array}$ & $\begin{array}{c}\text { Cooper's Cave, } \\
\text { Kromdraii }\end{array}$ & $\begin{array}{c}\text { McKee and Keyser (1994), } \\
\text { Williams et al. (2007), } \\
\text { Gilbert (2013) }\end{array}$ \\
\hline & P. h. robinsoni & Ditsong & 5 & $\begin{array}{c}\text { SK555, SK557, SK558, } \\
\text { SK560, SK562 }\end{array}$ & Swartkrans & $\begin{array}{c}\text { Carter (2006), } \\
\text { Geissler (2013), } \\
\text { Beaudet et al. (2016) }\end{array}$ \\
\hline & & UCMP & 2 & $\begin{array}{c}\text { UCMP 56767, UCMP } \\
56797\end{array}$ & Bolt's Farm & Freedman (1965) \\
\hline & & U Wits & 1 & SWP31 & Sterkfontein & Eisenhart (1974) \\
\hline & P. h. ursinus & Ditsong & 1 & TM211 & & Freedman (1957) \\
\hline & P. izodi & U Wits & 5 & $\begin{array}{l}\text { T89-11-1, TP4, TP7, } \\
\text { TP10, TP12 }\end{array}$ & Taung & $\begin{array}{c}\text { Gilbert and Grine (2010), } \\
\text { Gilbert (2013) }\end{array}$ \\
\hline & & Total & 19 & & & \\
\hline \multirow[t]{9}{*}{ Parapapio } & P. broomi & Ditsong & 6 & $\begin{array}{l}\text { STS254A, STS262, } \\
\text { STS393, STS396A, } \\
\text { STS397, STS564 }\end{array}$ & Sterkfontein & $\begin{array}{c}\text { Carter (2006), } \\
\text { Williams et al. (2007), } \\
\text { Gilbert (2013) }\end{array}$ \\
\hline & & UCMP & 1 & UCMP 56786 & Bolt's Farm & Freedman (1965) \\
\hline & & U Wits & 7 & $\begin{array}{l}\text { M3056, M3065, MP151, } \\
\text { MP2, MP224, MP76, } \\
\text { SWP12 }\end{array}$ & $\begin{array}{l}\text { Makapansgat, } \\
\text { Sterkfontein }\end{array}$ & $\begin{array}{l}\text { Fourie (2006), } \\
\text { Fourie et al. (2008), } \\
\text { Gilbert (2013) }\end{array}$ \\
\hline & P. jonesi & Ditsong & 2 & STS260, STS565 & Sterkfontein & $\begin{array}{l}\text { Pickering et al. (2004), } \\
\text { Fourie et al. (2008), } \\
\text { Gilbert (2013) }\end{array}$ \\
\hline & & U Wits & 5 & $\begin{array}{l}\text { M3060, MP75, MP173, } \\
\text { SWP389, SWP2947 }\end{array}$ & $\begin{array}{l}\text { Makapansgat, } \\
\text { Sterkfontein }\end{array}$ & Maier (1970) \\
\hline & P. whitei & UCMP & 1 & UCMP 56614 & $\begin{array}{c}\text { Buxton } \\
\text { Limeworks }\end{array}$ & Freedman (1965) \\
\hline & & U Wits & 10 & $\begin{array}{l}\text { BF43, M3070, M3072, } \\
\text { M3147, MP119, MP164, } \\
\text { MP208, MP221, MP223, } \\
\text { MP239 }\end{array}$ & $\begin{array}{l}\text { Bolt's Farm, } \\
\text { Makapansgat }\end{array}$ & $\begin{array}{c}\text { Maier (1977), } \\
\text { Williams et al. (2007), } \\
\text { Fourie et al. (2008), } \\
\text { Williams (2013) }\end{array}$ \\
\hline & unknown & U Wits & 4 & $\begin{array}{c}\text { M3053, M3084, M3133, } \\
\text { MP47 }\end{array}$ & Makapansgat & $\begin{array}{l}\text { Fourie (2006), } \\
\text { Fourie et al. (2008) }\end{array}$ \\
\hline & & Total & 36 & & & \\
\hline
\end{tabular}


TABLE 1 (continued).

\begin{tabular}{|c|c|c|c|c|c|c|}
\hline Genus & Species & Repository & $\mathbf{N}$ & Specimen numbers & Site(s) & References \\
\hline \multirow[t]{3}{*}{ Procercocebus } & P. antiquus & UCMP & 3 & $\begin{array}{l}\text { UCMP 56609, UCMP } \\
56694, \text { UCMP } 125956\end{array}$ & $\begin{array}{l}\text { Buxton } \\
\text { Limeworks }\end{array}$ & Gilbert (2007) \\
\hline & & U Wits & 5 & $\begin{array}{c}\text { M3078, M3079, T89- } \\
\text { 154, TP8, TP9 }\end{array}$ & $\begin{array}{l}\text { Makapansgat, } \\
\text { Taung }\end{array}$ & Gilbert (2013) \\
\hline & & Total & 8 & & & \\
\hline \multirow[t]{3}{*}{ Theropithecus } & T. darti & U Wits & 4 & $\begin{array}{l}\text { M3073, MP168, MP217, } \\
\text { MP222 }\end{array}$ & Makapansgat & $\begin{array}{c}\text { Maier (1972), } \\
\text { Williams et al. (2007), } \\
\text { Geissler (2013), } \\
\text { Gilbert (2013) }\end{array}$ \\
\hline & T. oswaldi & Ditsong & 2 & SK561, SK563 & Swartkrans & $\begin{array}{l}\text { Folinsbee and Reisz } \\
\qquad(2013)\end{array}$ \\
\hline & & Total & 6 & & & \\
\hline \multirow[t]{4}{*}{ unknown } & unknown & Ditsong & 6 & $\begin{array}{c}\text { SB2, SK3, SK556, } \\
\text { SK814, SKII25, STS537 }\end{array}$ & $\begin{array}{l}\text { Swartkrans, } \\
\text { Sterkfontein }\end{array}$ & $\mathrm{N} / \mathrm{A}$ \\
\hline & & UCMP & 1 & UCMP 218738 & $\begin{array}{c}\text { Buxton } \\
\text { Limeworks }\end{array}$ & Monson et al. (2015) \\
\hline & & U Wits & 10 & $\begin{array}{l}\text { unnumbered black skull, } \\
\text { MP4A, SP1, SP24, } \\
\text { SWP1728, SWP1731, } \\
\text { SWP29, SWP2953, } \\
\text { T8817, T9087 }\end{array}$ & $\begin{array}{l}\text { Makapansgat, } \\
\text { Sterkfontein, } \\
\text { Taung }\end{array}$ & $\mathrm{N} / \mathrm{A}$ \\
\hline & & Total & 17 & & & \\
\hline TOTAL & & & 99 & & & \\
\hline
\end{tabular}

Freedman, 1962; Frost et al., 2003; Singleton, 2002; Leigh, 2006). We conducted a size-free analysis of shape variation focused on morphological and taxonomic variation in adult forms using our sample of fossil and extant cercopithecids. In order to remove absolute scale from our data while retaining the signals of shape, we used geometric mean (GM) size-correction. Geometric mean sizecorrection, in the Mosimann size-correction family, requires a complete data set without missing data (Mosimann, 1970). Using two different subsets of measurements, chosen to maximize the number of specimens and measurements included, we ran geometric mean size-correction on both the extant and fossil samples.

We calculated the correlation between pairs of craniofacial measurements by generating a correlation matrix using the rcorr function in Hmisc (Harrell and Dupont, 2012). All correlations were calculated using only the papionins and unknown samples, and excluding the five Cercopithecoides specimens. We used a Bonferroni correction of $p<$ 0.00037 for 136 comparisons to evaluate the significance of correlation between cranial measurements.

\section{RESULTS}

For all of the traits measured, there is significant overlap in values for all fossil taxa (genus level data reported in Table 4; species level data reported in Appendix 4). Face length, maximum cranial length, and palate length show the greatest range of variation in the sample. There is no clear relationship between trait values and taxonomic designation, demonstrating that these measurements do not distinguish fossil taxa. Bivariate plots using various pairs of cranial measurements show that these measurements are highly correlated, and simultaneously reveal a nearly random distribution of fossil taxa (Figure 2). While extant species group together and are size-sorted on the bivariate plots, the fossil specimens show no such grouping despite occupying a large range of the size variation seen in the extant taxa.

The MANOVA finds that these 17 cranial measurements are not significantly different between fossil papionins. In contrast, the raw cranial measurements of the extant papionins are significantly different at $p<0.001$ (Table 5). Comparing individual measurements between genera, many of the statistical differences are between Cercopithecoides $(n=5)$ and the other fossil genera sampled, primarily in measures of muzzle width, palate 


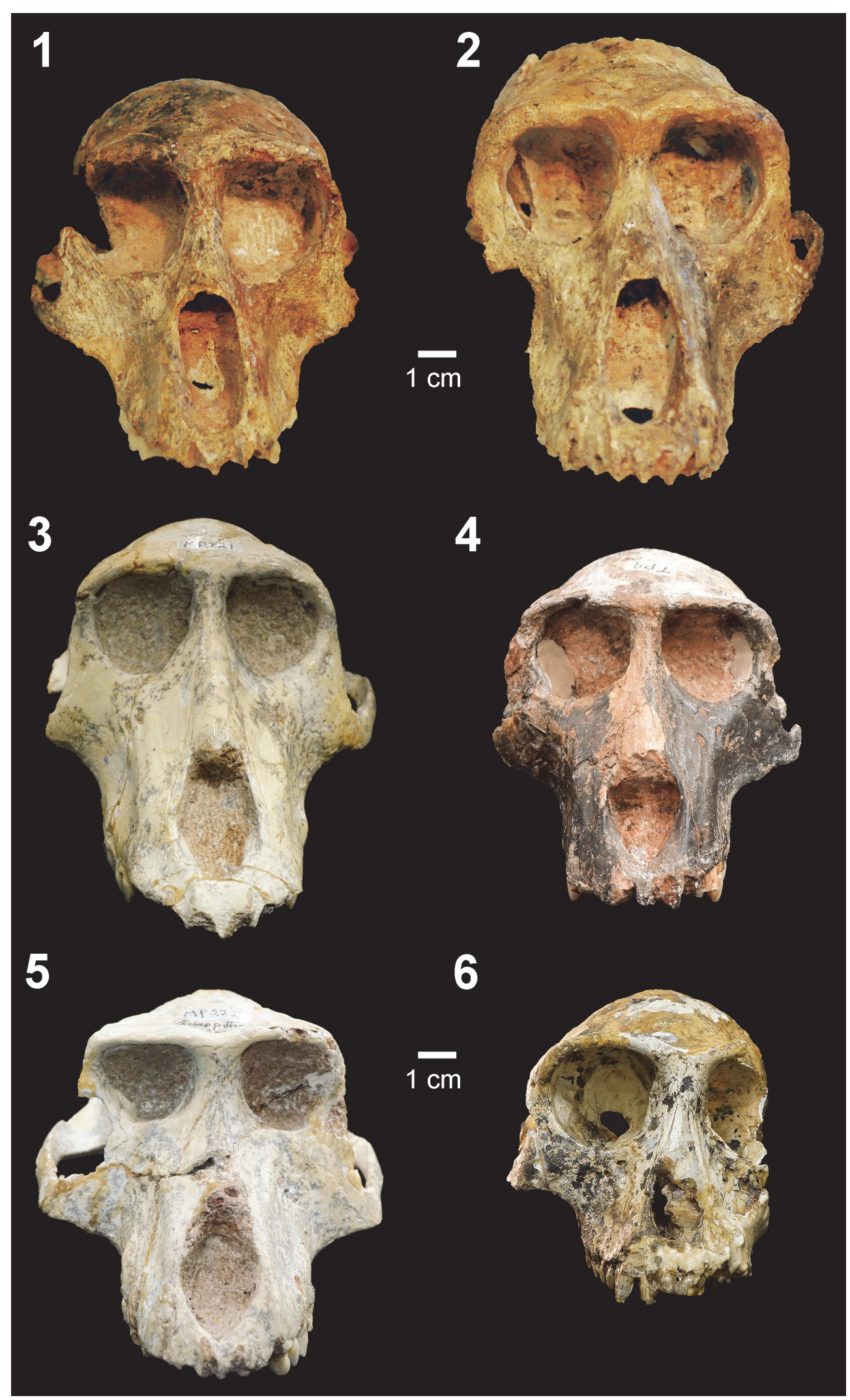

FIGURE 1. Six of the fossil cercopithecid specimens used in this study. 1, UCMP 125854, Papio izodi. 2, UCMP 125856, Papio izodi. 3, MP221, Parapapio jonesi. 4, TP9, Procercocebus antiquus. 5, MP222, Theropithecus darti. 6 , STS394A, Cercopithecoides williamsi. 
TABLE 2. Extant papionin species represented and sample sizes used in this study. All specimens are from the National Museum of Natural History in Washington D.C., USA, with the exception of one Theropithecus specimen from the National Museum in Addis Ababa, Ethiopia.

\begin{tabular}{lc}
\hline \multicolumn{1}{c}{ Species } & Sample size (n) \\
\hline Cercocebus torquatus & 20 \\
Lophocebus albigena & 15 \\
Mandrillus sphinx & 7 \\
Papio hamadryas & 34 \\
Theropithecus gelada & 5 \\
\hline \multicolumn{1}{c}{ Total } & $\mathbf{8 1}$ \\
\hline
\end{tabular}

length, and interorbital breadth relative to the papionins (Appendix 5), traits which also distinguish extant colobines from papionins (Jablonski and Frost, 2010). Other differences include the cranium of fossil Theropithecus ( $n=5)$, which is found to be significantly wider than that Papio $(n=19)$ and Procercocebus $(n=7)$, and the palate length of Papio, which is significantly longer than that of Parapapio $(n=38)$. Dinopithecus $(n=5)$ is also significantly larger than several of the other taxa in some measurements. Many of these differences between fossil cercopithecids have also been highlighted when qualitatively described (e.g., Freedman, 1957, 1961; Heaton, 2006). Despite the differences we find, overall, only $3.1 \%$ (11 out of 357 ) of the statistical comparisons are statistically significantly different suggesting that very few traits distinguish any of these taxa despite the sample encompassing both geographic and temporal variation.

Our ANOVA on a subset of GM scaled data pulls out more differences between fossil taxa, although not nearly as many as seen in the sample of extant species. While $64 \%$ of the scaled measurements are significantly different across extant papionins (Table 6 ), only $10.7 \%$ of the scaled measurements are significantly different across South African fossil cercopithecids (Table 7). Again, Cercopithecoides and Theropithecus are both distinguished from the other fossil taxa by measurements of the muzzle and palate. Parapapio and Papio are also distinct from each other in muzzle width (ectomolare) and palate length, features that have been consistently used to distinguish these fossil genera (e.g., Freedman, 1957, 1961; Heaton, 2006). An additional ANOVA on a different subset of GM scaled measurements pro-

TABLE 3. Definitions of cranial measurements.

\begin{tabular}{|c|c|}
\hline Measurement & Definition \\
\hline Maximum length & Maximum length of the cranium from prosthion to inion. \\
\hline Maximum breadth & Maximum breadth of the cranium posterior to the external auditory meatus. \\
\hline Orbital width & Maximum width of the orbit along a line perpendicular to the orbital height. \\
\hline Orbital height & Maximum height of the orbit along a parasagittal plane. \\
\hline Interorbital breadth & Breadth between the superomedial margins of the orbits. \\
\hline Nasal width & Maximum width of the nasal aperture, from left to right alare. \\
\hline Nasal height & Maximum height of the nasal aperture, from nasospinale to rhinion. \\
\hline Muzzle width (ectomolare) & Maximum width of the muzzle, measured at the ectomolare. \\
\hline Muzzle width (maxillary fossae) & $\begin{array}{l}\text { Maximum width of the muzzle, measured at the superior border of the maxillary fossae, } \\
\text { inferior to the orbits. }\end{array}$ \\
\hline Maximum width (canine) & Maximum width of the muzzle, measured at the canine alveoli. \\
\hline Maximum zygofrontal width & Maximum width of the upper face, measured from left to right frontomalare temporale. \\
\hline $\begin{array}{l}\text { Maximum calvarial width (post- } \\
\text { orbital constriction) }\end{array}$ & Maximum calvarial width, measured at the post-orbital constriction. \\
\hline Calvarial length & Maximum calvarial length, measured from ophryon to inion. \\
\hline Palate width $\left(\mathrm{M}^{3}\right)$ & $\begin{array}{l}\text { Maximum width of the palate, measured from the lateral edges of the depth of the palate, } \\
\text { along a line bisecting the third molars. }\end{array}$ \\
\hline Palate width (canine) & $\begin{array}{l}\text { Maximum width of the palate, measured from the lateral edges of the depth of the palate, } \\
\text { along a line bisecting the most medial points of the canine alveoli. }\end{array}$ \\
\hline Palate length & Maximum length of the palate, measured from orale to staphylion. \\
\hline Face length & Projection of the face, measured from prosthion to glabella. \\
\hline
\end{tabular}


TABLE 4. Sample size, mean, and standard deviation of each measurement for the fossil genera sampled in this study. All measurements are in millimeters.

\begin{tabular}{|c|c|c|c|c|c|c|c|c|c|c|c|c|c|c|c|c|}
\hline \multirow{3}{*}{$\begin{array}{c}\text { Genus } \\
\begin{array}{c}\text { Sample } \\
\text { size }\end{array} \\
\text { Statistic }\end{array}$} & \multicolumn{2}{|c|}{ 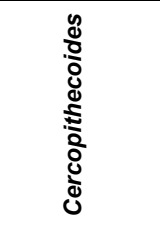 } & \multicolumn{2}{|c|}{ 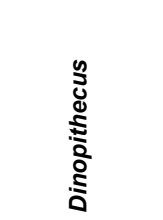 } & \multicolumn{2}{|c|}{ 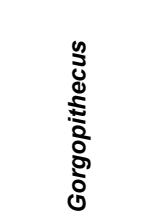 } & \multicolumn{2}{|c|}{$\frac{\frac{0}{2}}{\frac{\pi}{0}}$} & \multicolumn{2}{|c|}{$\begin{array}{l}\frac{0}{2} \\
\frac{2}{\pi} \\
\frac{\mathbb{\pi}}{\mathbb{2}}\end{array}$} & \multicolumn{2}{|c|}{ 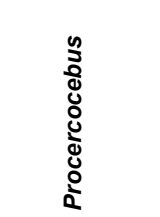 } & \multicolumn{2}{|c|}{ 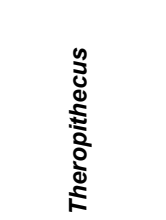 } & \multicolumn{2}{|c|}{ 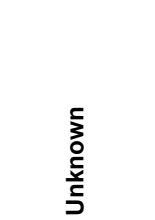 } \\
\hline & \multicolumn{2}{|c|}{5} & \multicolumn{2}{|c|}{5} & \multicolumn{2}{|c|}{3} & \multicolumn{2}{|c|}{19} & \multicolumn{2}{|c|}{36} & \multicolumn{2}{|c|}{8} & \multicolumn{2}{|c|}{6} & \multicolumn{2}{|c|}{17} \\
\hline & Mean & SD & Mean & SD & Mean & SD & Mean & SD & Mean & SD & Mean & SD & Mean & SD & Mean & SD \\
\hline Max. length & 124.9 & NA & 173.9 & 21.7 & NA & NA & 148.2 & 9.8 & 152.4 & 19.9 & 147.9 & 16.5 & 171.5 & 8.1 & 163.9 & 30.6 \\
\hline $\begin{array}{l}\text { Max. } \\
\text { breadth }\end{array}$ & 81.6 & 6.2 & 87.1 & 5.9 & NA & NA & 71.6 & 2.0 & 76.2 & 5.5 & 70.9 & 7.2 & 84.1 & 5.3 & 77.6 & 6.6 \\
\hline Orb. width & 29.4 & 2.2 & 30.1 & 6.0 & NA & NA & 27.5 & 1.9 & 26.9 & 2.2 & 26.4 & 1.6 & 28.7 & 2.4 & 27.0 & 2.3 \\
\hline Orb. height & 27.9 & 0.8 & 30.1 & 6.0 & NA & NA & 24.3 & 3.0 & 24.5 & 2.4 & 23.5 & 1.5 & 26.9 & 4.9 & 25.3 & 3.5 \\
\hline $\begin{array}{l}\text { Interorb. } \\
\text { breadth }\end{array}$ & 15.0 & 2.9 & 11.9 & 5.9 & NA & NA & 11.5 & 2.7 & 11.4 & 2.0 & 8.9 & 1.2 & 12.1 & 1.5 & 11.8 & 2.4 \\
\hline Nas. width & 14.9 & 2.5 & 16.1 & 3.5 & 16.4 & NA & 19.1 & 4.0 & 17.6 & 2.4 & 17.7 & 1.8 & 18.9 & 1.7 & 18.0 & 2.0 \\
\hline Nas. height & 18.8 & NA & 27.6 & 1.8 & NA & NA & 29.8 & 9.1 & 26.5 & 4.2 & 25.8 & 2.7 & 29.3 & 2.4 & 29.3 & 8.0 \\
\hline $\begin{array}{l}\text { Muz. width } \\
\text { (ecto.) }\end{array}$ & 44.6 & 2.2 & 58.6 & 10.2 & 58.2 & NA & 51.4 & 8.0 & 51.2 & 4.2 & 46.8 & 2.4 & 51.9 & 3.1 & 48.1 & 6.6 \\
\hline $\begin{array}{l}\text { Muz. width } \\
\text { (max. f.) }\end{array}$ & 25.5 & 3.9 & 39.9 & 5.8 & NA & NA & 40.0 & 8.9 & 37.1 & 4.4 & 36.4 & 4.2 & 35.5 & 4.5 & 39.4 & 5.4 \\
\hline $\begin{array}{l}\text { Max. width } \\
\text { (C) }\end{array}$ & 30.6 & 2.7 & 38.7 & 9.4 & 43.0 & 3.4 & 41.4 & 11.3 & 36.6 & 5.8 & 35.2 & 4.1 & 33.8 & 2.1 & 38.6 & 4.8 \\
\hline $\begin{array}{l}\text { Max. } \\
\text { zygofront } \\
\text { width }\end{array}$ & 81.0 & 3.2 & 88.1 & 21.3 & NA & NA & 72.4 & 6.5 & 72.4 & 6.9 & 75.8 & 4.9 & 77.1 & 1.1 & 80.5 & 5.4 \\
\hline $\begin{array}{l}\text { Max. cal. } \\
\text { width }\end{array}$ & 54.9 & 3.8 & 54.1 & 0.9 & NA & NA & 53.4 & 5.8 & 53.3 & 3.0 & 56.4 & 3.6 & 48.2 & 4.7 & 53.4 & 3.5 \\
\hline Cal. length & 94.4 & 10.7 & 92.3 & NA & NA & NA & 88.5 & 3.5 & 94.3 & 8.3 & 87.9 & 4.7 & 95.4 & 10.5 & 90.8 & 6.6 \\
\hline $\begin{array}{l}\text { Palate } \\
\text { width }\left(\mathrm{M}^{3}\right)\end{array}$ & 19.2 & 1.5 & 25.1 & 6.9 & 25.9 & 7.1 & 23.9 & 5.2 & 24.1 & 2.3 & 20.5 & 2.7 & 24.3 & 4.7 & 21.2 & 2.9 \\
\hline $\begin{array}{l}\text { Palate } \\
\text { width (C) }\end{array}$ & 18.8 & 1.8 & 27.8 & 8.1 & 23.6 & 0.0 & 24.2 & 6.2 & 21.5 & 3.0 & 17.8 & 2.8 & 20.4 & 1.1 & 22.0 & 3.0 \\
\hline $\begin{array}{l}\text { Palate } \\
\text { length }\end{array}$ & 40.4 & 2.1 & 68.9 & 10.5 & 65.5 & 4.4 & 67.4 & 16.9 & 51.5 & 8.2 & 51.2 & 6.0 & 62.9 & 3.8 & 57.6 & 11.7 \\
\hline $\begin{array}{l}\text { Face } \\
\text { length }\end{array}$ & 62.4 & 6.5 & 98.7 & 29.7 & NA & NA & 99.0 & 30.7 & 82.2 & 11.6 & 76.1 & 10.6 & 93.0 & 0.9 & 94.0 & 28.6 \\
\hline
\end{tabular}

duces similar results, with extant papionins showing substantially more discrimination among them than between the fossil taxa (Appendices 6 and 7).

Plotting the raw data in multivariate space also fails to show a clear distinction between the majority of fossil genera and/or species. We explored several iterations of a principle components analysis using subsets of the measurements (Figure 3). These subsets of traits clearly distinguish the extant papionins, with the exception of Lophocebus and Cercocebus. However, Lophocebus and Cercocebus are so morphologically similar that their taxonomic status and phylogenetic position were a significant source of controversy until fairly recently (e.g., Disotell, 2000; Fleagle and McGraw, 2002; Singleton, 2002). Among the fossils, some combinations of traits discriminate the colobine Cercopithecoides, as well as the more recent Papio hamadryas, from the fossil papionins. However, no combination of traits discriminates other Papio species from Parapapio, Procercocebus, or Dinopithecus. Fossil Theropithecus also tends to fall into the cluster of South African papionins rather than as a discrete cluster.

As the bivariate plots reveal, many of the cranial measurements used in this study are significantly correlated. Maximum cranial length and muzzle width (ectomolare) are each significantly 


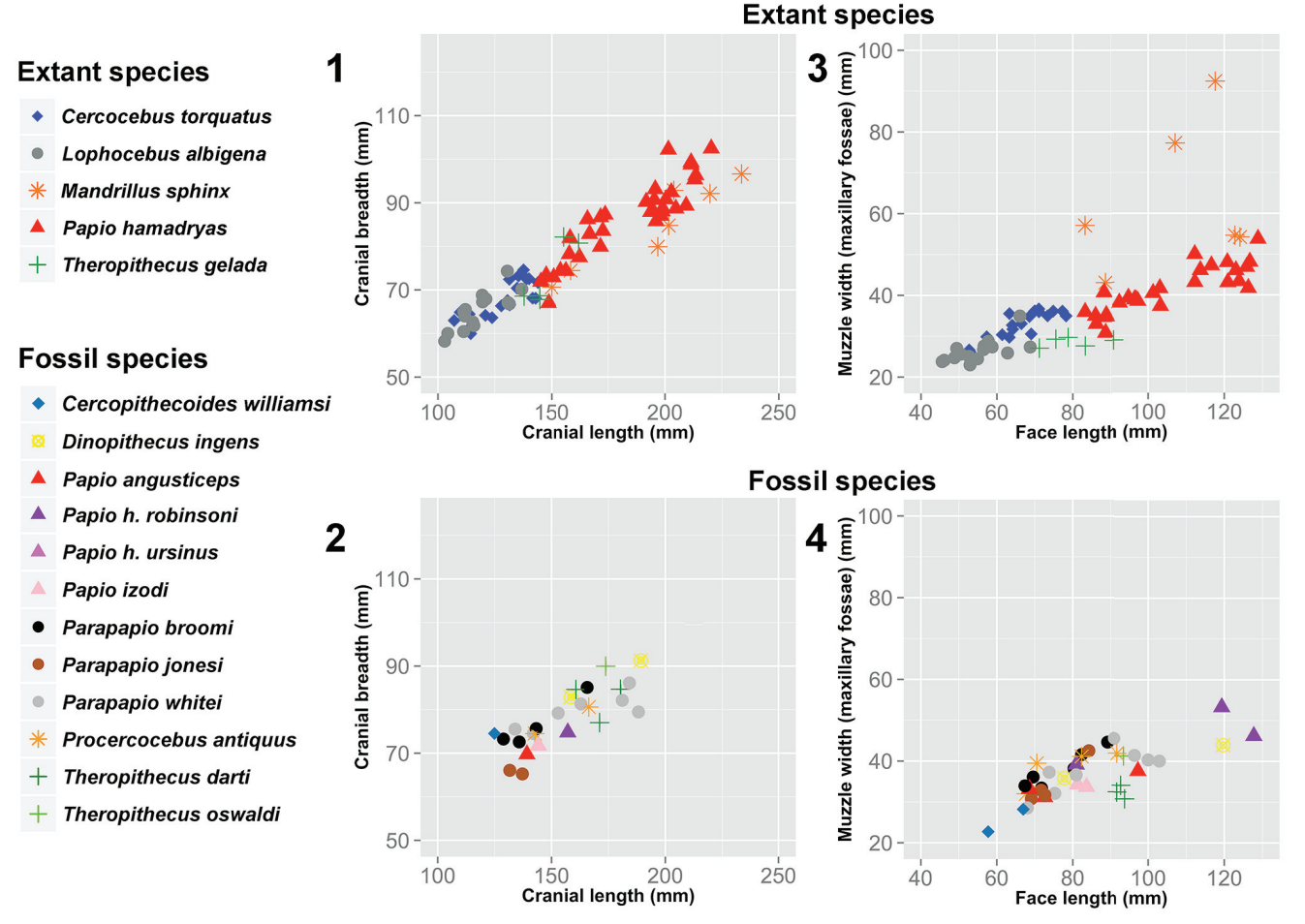

FIGURE 2. Bivariate plots of cranial measurements of extant papionins and the fossil sample. 1 and 2, Bivariate plot comparing cranial length and cranial breadth in extant papionins (1) and the fossil sample (2). 3 and 4, Bivariate plot comparing face length and muzzle width (ectomolare) in extant papionins (3) and the fossil sample (4). Note high correlations and the lack of a consistent taxonomic pattern across the distribution of fossil specimens. All bivariate correlations are significant at $p<0.0004$.

correlated with 12 of the other measurements, with all significant correlations exceeding $r=0.578$. Muzzle width (maxillary fossae; see Table 3 for measurement description) and face length are each significantly correlated with 11 of the 16 other cranial measurements, again with high estimated correlations, exceeding $r=0.521$. Orbital width, interorbital breadth, nasal width, maximum width at the canines, palate width at the canines, and palate length are all significantly correlated with at least nine other measurements, with correlations ranging from $r=0.514$ to $r=0.880$. Other significant and highly correlated pairs of measurements include face length and cranial length $(r=0.898)$, cranial length and palate length $(r=0.880)$, maximum zygofrontal width and orbital width $(r=0.835)$, palate length and face length $(r=0.827)$, cranial length and cranial breadth $(r=0.817)$, and cranial length and calvarial length $(r=0.814)$. Seven of the cranial measurements have fewer than nine significant correlations: maximum cranial breadth, orbital height, nasal height, maximum zygofrontal width, maximum calvarial width (post-orbital constriction), calvarial length, and palate width at the third molars. Overall, almost half of the 136 possible correlations are statistically significant. Table 8

TABLE 5. Results of the MANOVA for the extant and fossil papionins. Double asterisks denote significance at $p<$ 0.001 .

\begin{tabular}{lcc}
\hline \multicolumn{1}{c}{ Traits } & Group & $\boldsymbol{p}$ \\
\hline $\begin{array}{l}\text { Max. length, Max. breadth, Orb. width, Orb. height, Interorb. breadth, Nas. width, Nas. } \\
\text { height, Muz. width (ecto.), Muz. width (max. fos.), Max. cal. width }\end{array}$ & Extant & $0.000^{* *}$ \\
$\begin{array}{l}\text { Max. length, Max. breadth, Orb. width, Orb. height, Interorb. breadth, Nas. width, Nas. } \\
\text { height, Muz. width (ecto.), Muz. width (max. fos.), Max. cal. width }\end{array}$ & Fossil \\
$\begin{array}{l}\text { Cal. length, Palate width (M33), Palate width (C), Palate length, Face length } \\
\text { Cal. length, Palate width (M33), Palate width (C), Palate length, Face length }\end{array}$ & Extant & 0.439 \\
\end{tabular}


TABLE 6. ANOVA results for the size-corrected values of the extant sample, $\mathrm{n}=81$. MANOVA is significant at $p<2.2 \mathrm{e}-$ 16. Measurements are size-corrected using geometric mean (Mosimann, 1970). Shaded cells are significant at $p<$ 0.05 .

\begin{tabular}{lccccc}
\hline \multicolumn{1}{c}{ Genus Comparison } & $\begin{array}{c}\text { Muz. Width } \\
\text { (Ecto.) }\end{array}$ & $\begin{array}{c}\text { Muz. Width } \\
\text { (Canine) }\end{array}$ & $\begin{array}{c}\text { Palate Width } \\
\text { (Canine) }\end{array}$ & Palate Length & Face Length \\
\hline Lophocebus-Cercocebus & 0.087 & 0.017 & 0.017 & 0.980 & 0.036 \\
Mandrillus-Cercocebus & 0.000 & 0.712 & 0.712 & 0.000 & 0.002 \\
Papio-Cercocebus & 0.000 & 0.040 & 0.040 & 0.000 & 0.000 \\
Theropithecus-Cercocebus & 1.000 & 0.224 & 0.224 & 0.000 & 0.000 \\
Mandrillus-Lophocebus & 0.000 & 0.007 & 0.007 & 0.000 & 0.000 \\
Papio-Lophocebus & 0.000 & 0.000 & 0.000 & 0.000 & 0.000 \\
Theropithecus-Lophocebus & 0.522 & 0.001 & 0.001 & 0.000 & 0.000 \\
Papio-Mandrillus & 0.192 & 0.987 & 0.987 & 0.991 & 0.024 \\
Theropithecus-Mandrillus & 0.000 & 0.938 & 0.938 & 0.007 & 0.438 \\
Theropithecus-Papio & 0.000 & 0.986 & 0.986 & 0.000 & 0.957
\end{tabular}

TABLE 7. ANOVA results for a subset of the size-corrected values of the fossil sample, $\mathrm{n}=38$. MANOVA is significant at $p<0.0009$. Measurements are size-corrected using geometric mean (Mosimann, 1970). Shaded cells are significant at $p<0.05$.

\begin{tabular}{lccccc}
\hline \multicolumn{1}{c}{ Genus Comparison } & $\begin{array}{c}\text { Muz. Width } \\
\text { (Ecto.) }\end{array}$ & $\begin{array}{c}\text { Muz. Width } \\
\text { (Canine) }\end{array}$ & $\begin{array}{c}\text { Palate Width } \\
\text { (Canine) }\end{array}$ & Palate Length & Face Length \\
\hline Dinopithecus-Cercopithecoides & 0.404 & 0.687 & 0.991 & 0.140 & 0.355 \\
Papio-Cercopithecoides & 0.035 & 0.966 & 0.930 & 0.004 & 0.300 \\
Parapapio-Cercopithecoides & 0.876 & 0.998 & 1.000 & 0.980 & 0.853 \\
Procercocebus-Cercopithecoides & 0.855 & 0.999 & 0.504 & 0.301 & 0.771 \\
Theropithecus-Cercopithecoides & 0.733 & 0.152 & 0.647 & 0.011 & 0.088 \\
Papio-Dinopithecus & 0.975 & 0.895 & 1.000 & 0.966 & 0.998 \\
Parapapio-Dinopithecus & 0.682 & 0.651 & 0.981 & 0.103 & 0.642 \\
Procercocebus-Dinopithecus & 0.855 & 0.318 & 0.892 & 0.938 & 0.882 \\
Theropithecus-Dinopithecus & 0.958 & 0.963 & 0.954 & 0.982 & 0.998 \\
Parapapio-Papio & 0.005 & 0.979 & 0.607 & 0.000 & 0.421 \\
Procercocebus-Papio & 0.099 & 0.605 & 0.800 & 0.167 & 0.912 \\
Theropithecus-Papio & 0.292 & 0.150 & 0.932 & 1.000 & 0.842 \\
Procercocebus-Parapapio & 1.000 & 0.837 & 0.090 & 0.169 & 0.997 \\
Theropithecus-Parapapio & 0.983 & 0.025 & 0.236 & 0.001 & 0.089 \\
Theropithecus-Procercocebus & 0.999 & 0.011 & 1.000 & 0.342 & 0.400 \\
\hline
\end{tabular}




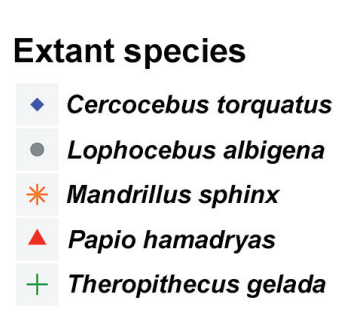

\section{Fossil species}

Cercopithecoides molletti

- Cercopithecoides williamsi Dinopithecus ingens

- Papio angusticeps

- Papio h. robinsoni

$\triangle$ Papio h. ursinus

Papio izodi

- Parapapio broomi

- Parapapio jonesi

- Parapapio whitei

Procercocebus antiquus

Theropithecus darti

Theropithecus oswaldi

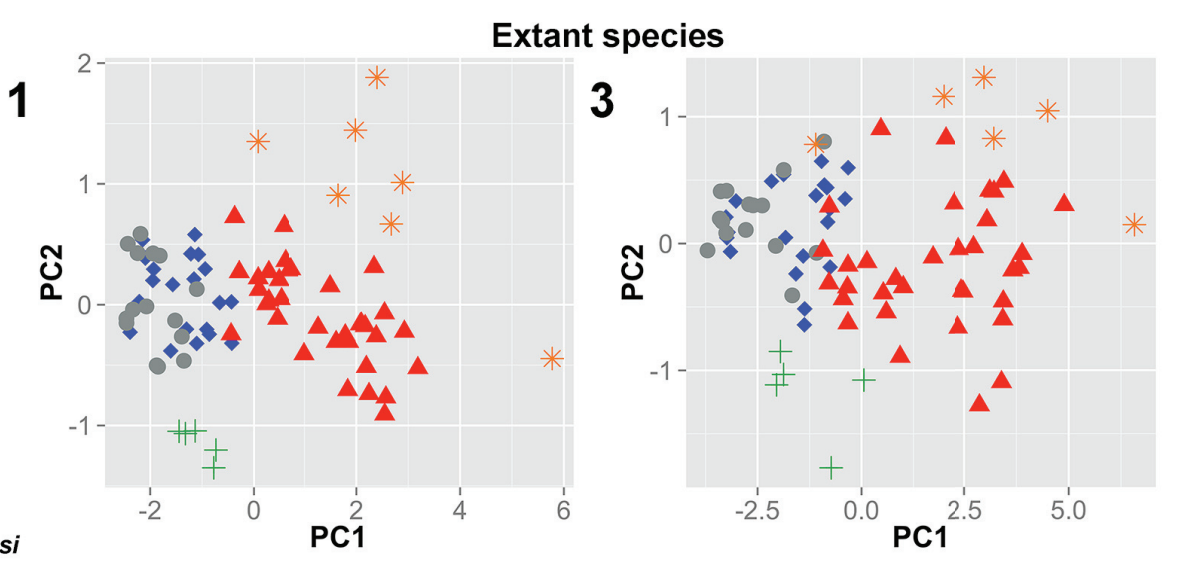

Fossil species

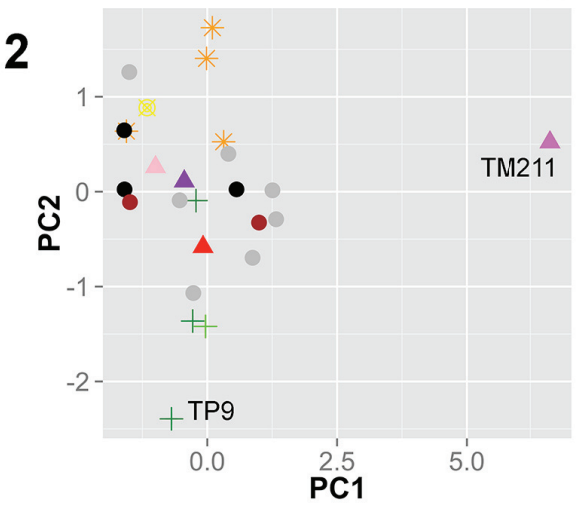

FIGURE 3. Principle components analyses (PCA) of cranial variation in extant papionins and the fossil sample. 1 and 2, PCA including maximum cranial length, orbital width, interorbital breadth, and palate length raw measurements for 81 extant papionins (1) and 25 fossil cercopithecids (2). PC1 and PC2 of the extant sample comprise $82.2 \%$ and $8.1 \%$ of the variation, respectively, and PC1 and PC2 of the fossil sample comprise $67.8 \%$ and $21.6 \%$ of the variation, respectively. Note how well the measurements discriminate extant species, and how Papio $h$. ursinus (TM211) and one specimen of Theropithecus darti (TP9) are distinct from the other fossils. 3 and 4, PCA including orbital width, interorbital breadth, muzzle width (ectomolare), maximum width (canine), palate width $\left(\mathrm{M}^{3}\right)$, palate width (canine), and palate length in 81 extant papionins (3) and 33 fossil cercopithecids (4). PC1 and PC2 of the extant sample comprise $86.6 \%$ and $4.8 \%$ of the variation, respectively, and PC1 and PC2 of the fossil sample comprise $66.1 \%$ and $12.7 \%$ of the variation, respectively. Note how well the measurements discriminate extant species, and that Cercopithecoides and Papio hamadryas are distinct from the other fossils.

details the correlations and sample sizes for a subset of measurement pairs. See Appendix 8 for the complete correlation matrix of GM scaled measurements.

\section{DISCUSSION}

Our results demonstrate that cranial linear metrics are unlikely to resolve the taxonomic puzzle that has characterized South African fossil primate taxonomy. We find pervasive phenotypic correlations across 17 measurements of craniofacial size in fossil papionins. This result is not surprising given the large body of literature on allometry of the cranium in cercopithecids (Freed- man, 1962; Albrecht, 1978; O'Higgins and Jones, 1998; Collard and O'Higgins, 2001; Singleton, 2002; Frost et al., 2003; Leigh et al., 2003; Leigh, 2006; Cardini and Elton, 2008). We also find that a long cranium and wide muzzle are highly correlated and scale allometrically with the size and shape of a variety of other facial features. The length of the face, for example, is significantly correlated with the width of the muzzle at the canines $(r=0.744, p<0.001)$. Likewise, the maximum length and breadth of the cranium are significantly correlated $(r=0.817, p<0.001)$.

These correlations correspond, to some extent, with what is known about craniofacial mod- 
TABLE 8. Sample size and correlations for a subset of size-corrected measurement comparisons. A full correlation matrix comparing all size-corrected measurements is available in Appendix 8. All correlations are significant at $p<$ 0.0004 . "(C)" is the abbreviation for canine.

\begin{tabular}{llc}
\hline \multicolumn{1}{c}{ Measurement pair } & $\begin{array}{c}\text { Sample size } \\
(\mathbf{n})\end{array}$ & $\begin{array}{c}\text { Correlation } \\
(\boldsymbol{r})\end{array}$ \\
\hline Maximum length - face length & 31 & 0.898 \\
Maximum length - palate length & 35 & 0.880 \\
Maximum zygofrontal width - orbital width & 32 & 0.835 \\
Palate length - face length & 45 & 0.827 \\
Maximum length - maximum breadth & 29 & 0.817 \\
Maximum length - calvarial length & 31 & 0.814 \\
Maximum width (C) - palate width (c) & 54 & 0.798 \\
Calvarial length - face length & 29 & 0.784 \\
Calvarial length - maximum breadth & 39 & 0.770 \\
Muzzle width ectomolare - palate width (C) & 54 & 0.764 \\
Face length - nasal height & 35 & 0.760 \\
Maximum width (C) - face length & 43 & 0.758 \\
\hline
\end{tabular}

ularity in primates. For example, maximum cranial breadth is only correlated with two other measurements: calvarial length, another measure of the vault, and maximum cranial length. We also recover a large number of statistically significant correlations within the face module. Interorbital breadth is significantly correlated with measures of muzzle width, palate width, and face length. Muzzle width (ectomolare) is also significantly correlated with a number of measurements of the face, including nasal height and width, muzzle width (at the canine, and at the maxillary fossae), palate length and width, and face length.

Maximum cranial length is found to be correlated with the majority of craniofacial measurements used in this study. Previous researchers report that cranial and mandible length are some of the best osteological predictors of body mass, with $R^{2}$ values exceeding 0.50 in New World Monkeys (Sears et al., 2008), and 0.90 in OWMs and apes (Fitch, 2000). In the Fitch (2000) study, face length and palate length were also highly correlated with body mass. These results suggest that body size alone may account for a significant amount of the variation seen in many aspects of papionin cranial morphology, again, results that also align with the body of work on covariation of size and adult morphology (e.g., Singleton, 2002; Frost et al., 2003; Leigh, 2006).

Unlike other measurements, we find that orbital height and calvarial width at the post-orbital constriction are independent and uncorrelated with other measurements of the cranium. The lack of correlation between calvarial width at the postorbital constriction and other cranial measurements may be related to the trait's position between two major cranial modules: orbit and cranial vault. The lack of correlation between orbital height and other measurements, however, cannot be so explained. These results add to the body of literature with conflicting reports on the relationship between orbital area and body mass (e.g., Schultz, 1940; Aiello and Wood, 1994; Kappelman, 1996). Heritability analyses in a pedigreed macaque population suggest that orbital width is significantly influenced by the additive effects of genes (Joganic et al., 2012). However, growth of the orbit in primates may be strongly influenced by the size and orientation of the anterior cranial base (Lieberman et al., 2000). Species-specific patterned variation in orbit morphology has been demonstrated in some closely related hominoid taxa (Pearce et al., 2013). But to our knowledge, no studies have been conducted in the cercopithecids. We see no evidence in our study that orbital height discriminates between the papionins sampled here (Appendix 5).

\section{CONCLUSION}

Morphological variation is central to primate biology, evolution, taxonomy, and conservation (Isaac et al., 2004; Mace, 2004). While molecular studies have contributed immensely to our understanding of extant primate diversity (Yoder et al., 
2000; van Roosmalen and van Roosmalen, 2003; Craul et al., 2007), interpreting the evolution of that diversity is still largely in the realm of paleontological studies (see Kimbel and Rak, 1993; Plavcan, 1993; Rose and Bown, 1993; Hlusko, 2004, 2016; Hlusko et al., 2016).

Our analyses show that many measurements of the cranium and face of fossil South African papionins are highly correlated with each other, suggesting a high level of cranial phenotypic integration in this group similar to what is reported for extant OWMs. Excepting Papio hamadryas and Cercopithecoides sp., and a few measurements of Theropithecus and Dinopithecus, none of the cranial measurements discriminate between fossil taxa despite their ability to differentiate between extant species. Additionally, most of the measurements are significantly correlated with cranial length, which is known to significantly correlate with body size, an evolutionarily labile trait that varies geographically and temporally (e.g., Marshall and Corruccini, 1978; Lister, 1989). Overall, these cranial data cannot be used to support the hypothesis that a number of morphologically distinct cercopithecids were inhabiting South Africa during the Plio-Pleistocene. Further evaluation of craniofacial integration in extant papionins will contribute to our understanding of species variation in the fossil record and the evolution of cranial form in primates.

\section{ACKNOWLEDGMENTS}

The authors thank curators P. Holroyd (University of California Museum of Paleontology), L. Kgasi (Ditsong National Museum of Natural History), S. Potze (Ditsong National Museum of Natural History), and B. Zipfel (Evolutionary Studies Institute, University of the Witwatersrand) for access to specimens. This study was funded by the Palaeontological Scientific Trust (PAST) and the Human Evolution Research Center. A. Weitz provided helpful feedback and discussion, as did members of the Human Evolution Research Center. The authors would also like to thank two anonymous reviewers for their thoughtful comments and suggestions that greatly improved this manuscript.

\section{AUTHOR CONTRIBUTIONS}

T.M. wrote the manuscript with editing by L.H., D.S., and M.B.; L.H., D.S., M.B., and T.M. coauthored the grant that supported this work. D.S. provided logistical support in South Africa. L.H. led the research group in collecting the data. T.M. collected the cranial data and performed all analyses. All authors contributed to the intellectual content, context, and interpretation.

\section{REFERENCES}

Ackermann, R.R. 2005. Ontogenetic integration of the hominoid face. Journal of Human Evolution, 48:175197.

Ackermann, R.R. 2009. Morphological integration and the interpretation of fossil hominin diversity. Evolutionary Biology, 36:149-156.

Ackermann, R.R. and Cheverud, J.M. 2004. Morphological integration in primate evolution, p. 302-319. In Pigliucci, M. and Preston, K. (eds.), Phenotypic Integration: Studying the Ecology and Evolution of Complex Phenotypes. Oxford University Press, New York.

Aiello, L.C. and Wood, B.A. 1994. Cranial variables as predictors of hominine body mass. American Journal of Physical Anthropology, 95:409-426.

Albrecht, G.H. 1978. The craniofacial morphology of the Sulawesi macaques. Multivariate approaches to biological problems. Contributions to Primatology, 13:1151.

Beaudet, A., Braga, J., de Beer, F., Schillinger, B., Steininger, C., Vodopivec, V., and Zanolli, C. 2016. Neutron microtomography-based virtual extraction and analysis of a cercopithecoid partial cranium (STS 1039) embedded in a breccia fragment from Sterkfontein Member 4 (South Africa). American Journal of Physical Anthropology, 159:737-745.

Behrensmeyer, A.K., Todd, N.E., Potts, R., and McBrinn, G.E. 1997. Late Pliocene faunal turnover in the Turkana basin, Kenya and Ethiopia. Science, 278:15891594.

Berger, L.R., de Ruiter D.J., Churchill, S.E., Schmid, P., Carlson, K.J., Dirks, P.H., and Kibii, J.M. 2010. Australopithecus sediba: a new species of Homo-like australopith from South Africa. Science, 328:195204.

Berger, L.R., Hawks J., de Ruiter, D.J. Churchill, S.E., Schmid, P., Delezene, L.K., Kivell, T.L., Garvin, H.M., Williams, S.A., DeSilva, J.M., Skinner, M.M., Musiba, C.M., Cameron, N., Holliday, T.W., Harcourt-Smith, W., Ackermann, R.R., Bastir, M., Bogin, B., Bolter, D., Brophy, J., Cofran, Z.D., Congdon, K.A., Deane, A.S., Dembo, M., Drapeau, M., Elliott, M.C., Feuerriegel, E.M., Garcia-Martinez, D., Green, D.J., Gurtov, A., Irish, J.D., Kruger, A., Laird, M.F., Marchi, D., Meyer, M.R., Nalla, S., Negash, E.W., Orr, C.M., Radovcic, D., Schroeder, L., Scott, J.E., Throckmorton, Z., Tocheri, M.W., VanSickle, C., Walker, C.S., Wei, P., and Zipfel, B. 2015. Homo naledi, a new species of the genus Homo from the Dinaledi Chamber, South Africa. eLife, 4:e09560.

Broom, R. 1936. A new fossil baboon from the Transvaal. Annals of the Transvaal Museum, 18:393-396. 
Broom, R. 1937. On some new Pleistocene mammals from limestone caves of the Transvaal. South African Journal of Science, 33:750-768.

Broom, R. 1940. The South African Pleistocene cercopithecid apes. Annals of the Transvaal Museum, 20:89100.

Broom, R. and Robinson, J.T. 1949. A new type of fossil baboon, Gorgopithecus major. Proceedings of the Zoological Society of London, 119:379-387.

Cardini, A. and Elton, S. 2008. Variation in guenon skulls (I): species divergence, ecological and genetic differences. Journal of Human Evolution, 54(5):615-637.

Carter, B.D. 2006. Paleoecological Reconstructions of the South African Plio-Pleistocene Based on LowMagnification Dental Microwear of Fossil Primates. B.A. Thesis, Georgia State University.

Cheverud, J.M. 1982. Phenotypic, genetic, and environmental morphological integration in the cranium. Evolution, 36(3):499-516.

Cheverud, J.M. 1988. A comparison of genetic and phenotypic correlations. Evolution, 42:958-968.

Cheverud, J.M. 1996. Developmental integration and the evolution of pleiotropy. American Zoologist, 36:44-50.

Cheverud, J.M. and Buikstra, J.E. 1981. Quantitative genetics of skeletal nonmetric traits in the rhesus macaques on Cayo Santiago. II. Phenotypic, genetic, and environmental correlations between traits. American Journal of Physical Anthropology, 54:51-58.

Clarke, R.J., Howell, F.C., and Brain, C.K. 1970. More evidence of an advanced hominid at Swartkrans. Nature, 225(5239):1219-1222.

Clarke, R.J. and Tobias, P.V. 1995. Sterkfontein Member 2 foot bones of the oldest South African hominid. Science, 269(5223):521.

Collard, M. and O'Higgins, P. 2001. Ontogeny and homoplasy in the papionin monkey face. Evolution and Development, 3(5):322-331.

Craul, M., Zimmermann, E., Rasoloharijaona, S., Randrianambinina, B., and Radespiel, U. 2007. Unexpected species diversity of Malagasy primates (Lepilemur spp.) in the same biogeographical zone: a morphological and molecular approach with the description of two new species. BMC Evolutionary Biology, 7:8398.

Dart, R.A. 1925. Australopithecus africanus. Nature, 115:195-199.

Delson, E. 1984. Cercopithecid biochronology of the African Plio-Pleistocene: correlation among eastern and southern hominid-bearing localities. Courier Forschungsinstitut Senckenberg, 69:199-218.

Delson, E. 1988. Chronology of South African Australopith site units, p. 317-325. In Grine, F.E. (ed.), Evolutionary History of the Robust Australopithecines. Aldine de Gruyter, New York.

Delson, E. 1993. Theropithecus fossils from Africa and India and the taxonomy of the genus, p. 157-189. In Jablonski, N.G. (ed.), Theropithecus: The Rise and Fall of a Primate Genus. Cambridge University Press, Cambridge.
Disotell, T.R. 2000. Molecular systematics of the Cercopithecidae, p. 29-56. In Whitehead, P.F., Jolly, C.J. (eds.), Old World Monkeys. Cambridge University Press, Cambridge.

Eisenhart, W.L. 1974. Fossil cercopithecoids of Makapansgat and Sterkfontein. B.A. Thesis, Harvard University.

Faith, J.T. and Behrensmeyer, A.K. 2013. Climate change and faunal turnover: testing the mechanics of the turnover-pulse hypothesis with South African fossil data. Paleobiology, 39:609-627.

Fitch, W.T. 2000. Skull dimensions in relation to body size in nonhuman mammals: the causal bases for acoustic allometry. Zoology (Jena), 103:40-58.

Fleagle, J.G. and McGraw, W.S. 2002. Skeletal and dental morphology of African papionins: unmasking a cryptic clade. Journal of Human Evolution, 42(3):267292.

Folinsbee, K.E. and Reisz, R.R. 2013. New craniodental fossils of papionin monkeys from Cooper's D, South Africa. American Journal of Physical Anthropology, 151:613-629.

Fourie, N.H. 2006. Dietary ecology and niche separation among three closely related species (Parapapio jonesi, Pp. whitei and Pp. broomi) of South African Plio-Pleistocene Cercopithecoidea from Makapansgat Limeworks site. Ph.D. Dissertation, University of Cape Town.

Fourie, N.H., Lee - Thorp, J.A., and Ackermann, R.R. 2008. Biogeochemical and craniometric investigation of dietary ecology, niche separation, and taxonomy of Plio-Pleistocene cercopithecoids from the Makapansgat Limeworks. American Journal of Physical Anthropology, 135:121-135.

Freedman, L. 1957. The fossil cercopithecoidea of South Africa. Annals of the Transvaal Museum, 23:123-262.

Freedman, L. 1961. New cercopithecoid fossils, including a new species, from Taung, Cape Province, South Africa. Annals of the South African Museum. 46(1):1-19.

Freedman, L. 1962. Growth of muzzle length relative to calvaria length in Papio. Growth, 26:117-28.

Freedman, L. 1965. Fossil and subfossil primates from the limestone deposits at Taung, Bolt's Farm and Witkrans, South Africa. Palaeontologia Africana, 9:1948.

Frost, S.R., Marcus, L.F., Bookstein, F.L., Reddy, D.P., and Delson, E. 2003. Cranial allometry, phylogeography, and systematics of large-bodied papionins (Primates: Cercopithecinae) inferred from geometric morphometric analysis of landmark data. The Anatomical Record Part A: Discoveries in Molecular, Cellular, and Evolutionary Biology, 275(2):1048-1072.

Geissler, E. 2013. Dental microwear analysis of Cercopithecoides williamsi. M.A. Dissertation, Georgia State University.

Gilbert, C.C. 2007. Craniomandibular morphology supporting the diphyletic origin of mangabeys and a new 
genus of the Cercocebus/Mandrillus clade, Procercocebus. Journal of Human Evolution, 53:69-102.

Gilbert, C.C. 2013. Cladistic analysis of extant and fossil African papionins using craniodental data. Journal of Human Evolution, 64:399-433.

Gilbert, C.C. and Grine, F.E. 2010. Morphometric variation in the papionin muzzle and the biochronology of the South African Plio-Pleistocene karst cave deposits. American Journal of Physical Anthropology, 141:418-429.

Gilbert, C.C., Steininger, C.M., Kibii, J.M., and Berger, L.R. 2015. Papio cranium from the hominin-bearing site of Malapa: implications for the evolution of modern baboon cranial morphology and South African Plio-Pleistocene biochronology. PLOS ONE, 10(8):e0133361.

Goswami, A. and Polly, P.D. 2010. The influence of modularity on cranial morphological disparity in Carnivora and Primates (Mammalia). PLoS ONE, 5(3):e9517.

Granger, D.E., Gibbon, R.J., Kuman, K., Clarke, R.J., Bruxelles, L., and Caffee, M.W. 2015. New cosmogenic burial ages for Sterkfontein Member 2 Australopithecus and Member 5 Oldowan. Nature, 522:85-88.

Halim, A. 2008. Human Anatomy: Volume III: Head, Neck and Brain. I.K. International Publishing House, New Delhi.

Hallgrímsson, B., Willmore, K., Dorval, C., and Cooper, D.M. 2004. Craniofacial variability and modularity in macaques and mice. Journal of Experimental Zoology Part B, 302:20225.

Harrell, F.E. and Dupont, M.C. 2012. Package 'Hmisc'. $R$ : A Language and Environment for Statistical Computing. R Foundation for Statistical Computing, Vienna.

Harris, J.M. and White, T.D. 1979. Evolution of the PlioPleistocene African Suidae. Transactions of the American Philosophical Society, 69(2):1-128.

Haughton, S.H. 1925. Note on the occurrence of a species of baboon in limestone deposits near Taungs. Transactions of the Royal Society of South Africa, 12:68.

Havill, L.M., Mahaney, M.C., Cox, L.A., Morin, P.A., JosIyn, G., and Rogers, J. 2005. A quantitative trait locus for normal variation in forearm bone mineral density in pedigreed baboons maps to the ortholog of human chromosome 11q. Journal of Clinical Endocrinology and Metabolism, 90:3638-3645.

Heaton, J.L. 2006. Taxonomy of the Sterkfontein Fossil Cercopithecinae: The Papionini of Members 2 and 4 (Gauteng, South Africa). Ph.D. Dissertation, Indiana University.

Herries, A.I. and Adams, J.W. 2013. Clarifying the context, dating and age range of the Gondolin hominins and Paranthropus in South Africa. Journal of Human Evolution, 65:676-681.

Herries, A.I. and Shaw, J. 2011. Palaeomagnetic analysis of the Sterkfontein palaeocave deposits: implica- tions for the age of the hominin fossils and stone tool industries. Journal of Human Evolution, 60:523-539.

Hildebrand, M. and Goslow, G.E. 2001. Analysis of Vertebrate Structure. John Wiley and Sons, Inc., New York.

Hlusko, L.J. 2004. Integrating the genotype and phenotype in hominid paleontology. Proceedings of the National Academy of Sciences, 101:2653-2657.

Hlusko, L.J. 2016. Elucidating the evolution of hominid dentition in the age of phenomics, modularity, and quantitative genetics. Annals of Anatomy, 203:3-11.

Hlusko, L.J., Schmitt, C.A., Monson, T.A., Brasil, M.F., and Mahaney, M.C. 2016. The integration of quantitative genetics, paleontology, and neontology reveals genetic underpinnings of primate dental evolution. Proceedings of the National Academy of Sciences, 113(33):9262-9267.

Isaac, N.J., Mallet, J., and Mace, G.M. 2004. Taxonomic inflation: its influence on macroecology and conservation. Trends in Ecology and Evolution, 19:464-469.

Jablonski, N.G. 1994. New fossil cercopithecid remains from the Humpata Plateau, southern Angola. American Journal of Physical Anthropology, 94:435-64.

Jablonski, N.G. 2002. Fossil Old World monkeys: the late Neogene radiation, p. 255-299. In Hartwig, W. (ed.), The Primate Fossil Record. Cambridge University Press, Cambridge.

Jablonski, N.G. and Frost, S. 2010. Cercopithecoidea, p. 393-428. In Werdelin, L. and Sanders, W. (eds.), Cenozoic Mammals of Africa. University of California Press, Berkeley.

Joganic, J.L., Willmore, K.E., Roseman, C.C., Richtsmeier, J.T., Rogers, J., and Cheverud, J.M. 2012. Comparative quantitative genetic analysis of cranial capacity and craniofacial morphology in two closely related primate species, p. 37-59. In Wang, Q. (ed.), Bones, Genetics, and Behavior of Rhesus Macaques. Springer, New York.

Jolly, C.J. 2001. A proper study for mankind: analogies from the papionin monkeys and their implications for human evolution. American Journal of Physical Anthropology, 116:177-204.

Jones, T.R. 1937. A new fossil primate from Sterkfontein, Krugersdorp, Transvaal. South African Journal of Science, 33:709728.

Kappelman, J. 1996. The evolution of body mass and relative brain size in fossil hominids. Journal of Human Evolution, 30:243-276.

Kardong, K. 1995. Vertebrates: Comparative Anatomy, Function, Evolution. McGraw-Hill Higher Education, Boston.

Kimbel, W.H. and Rak, Y. 1993. The importance of species taxa in paleoanthropology and an argument for the phylogenetic concept of the species category, $p$. 461-484. In Kimbel, W. and Martin, L. (eds.), Species, Species Concepts and Primate Evolution. Springer, New York. 
Klingenberg, C.P. 2008. Morphological integration and developmental modularity. Annual Review of Ecology, Evolution and Systematics, 39:115-132.

Koh, C., Bates, E., Broughton, E., Do, N.T., Fletcher, Z., Mahaney, M.C., and Hlusko, L.J. 2010. Genetic integration of molar cusp size variation in baboons. American Journal of Physical Anthropology, 142:246260.

Leamy, L.J., Routman, E.J., and Cheverud, J.M. 1999. Quantitative trait loci for early - and late - developing skull characters in mice: a test of the genetic independence model of morphological integration. American Naturalist, 153:201-214.

Leigh, S.R. 2006. Cranial ontogeny of Papio baboons (Papio hamadryas). American Journal of Physical Anthropology, 130:71-84.

Leigh, S.R., Shah, N.F., and Buchanan, L.S. 2003. Ontogeny and phylogeny in papionin primates. Journal of Human Evolution, 45(4):285-316.

Lieberman, D. 2011. The Evolution of the Human Head. Harvard University Press, Boston.

Lieberman, D.E., Ross, C.F., and Ravosa, M.J. 2000. The primate cranial base: ontogeny, function, and integration. American Journal of Physical Anthropology, 113:117-169.

Lister, A.M. 1989. Rapid dwarfing of red deer on Jersey in the last interglacial. Nature, 342(6249):539-542.

Mace, G.M. 2004. The role of taxonomy in species conservation. Philosophical Transactions of the Royal Society of London B: Biological Sciences, 359:711719.

Maier, W. 1970. New fossil Cercopithecoidea from the lower Pleistocene cave deposits of the Makapansgat limeworks, South Africa. Palaeontologia Africana, 13:69-107.

Maier, W. 1972. The first complete skull of Simopithecus darti from Makapansgat, South Africa, and its systematic position. Journal of Human Evolution, 1:395405.

Maier, W. 1977. Chronology and biology of the South African australopithecines. Journal of Human Evolution, 6:89-93.

Marroig, G. and Cheverud, J.M. 2001. A comparison of phenotypic variation and covariation patterns and the role of phylogeny, ecology, and ontogeny during cranial evolution of New World monkeys. Evolution, 55:2576-2600.

Marshall, L.G. and Corruccini, R.S. 1978. Variability, evolutionary rates, and allometry in dwarfing lineages. Paleobiology, 4(2):101-119.

McKee, J.K. 1996. Faunal turnover patterns in the Pliocene and Pleistocene of southern Africa. South African Journal of Science, 92:111-113.

McKee, J.K. and Keyser, A.W. 1994. Craniodental remains of Papio angusticeps from the Haasgat cave site, South Africa. International Journal of Primatology, 15:823-841.

McKee, J.K., von Mayer, A., and Kuykendall, K.L. 2011. New species of Cercopithecoides from Haasgat,
North West Province, South Africa. Journal of Human Evolution, 60:83-93.

Mitteroecker, P. and Bookstein, F. 2008. The evolutionary role of modularity and integration in the hominoid cranium. Evolution, 62:943-958.

Monson, T.A., Brasil, M.F., and Hlusko, L.J. 2015. Materials collected by the southern branch of the UC Africa Expedition with a report on previously unpublished Plio-Pleistocene fossil localities. PaleoBios, 32:1-17.

Mosimann, J.E. 1970. Size allometry: size and shape variables with characterizations of the lognormal and generalized gamma distributions. Journal of the American Statistical Association, 65(330):930-945.

Nowak, R. 1991. Walker's Mammals of the World, 5th Edition, Volume 1. The Johns Hopkins University Press, Baltimore and London.

O'Higgins, P. and Jones, N. 1998. Facial growth in Cercocebus torquatus: an application of three-dimensional geometric morphometric techniques to the study of morphological variation. Journal of Anatomy, 193(2):251-272.

Olson, E.C. and Miller, R.L. 1958. Morphological Integration. University of Chicago Press, Chicago.

Partridge, T.C. 2005. Dating of the Sterkfontein hominids: progress and possibilities. Transactions of the Royal Society of South Africa, 60:107-109.

Partridge, T.C., Granger, D.E., Caffee, M.W., and Clarke, R.J. 2003. Lower Pliocene hominid remains from Sterkfontein. Science, 300:607-612.

Pearce, E., Stringer, C., and Dunbar, R.I. 2013. New insights into differences in brain organization between Neanderthals and anatomically modern humans. Proceedings of the Royal Society of London B: Biological Sciences, 280:20130168.

Pickering, T.R., Clarke, R.J., and Heaton, J.L. 2004. The context of Stw 573, an early hominid skull and skeleton from Sterkfontein Member 2: taphonomy and paleoenvironment. Journal of Human Evolution, 46:277-295.

Pickering, R. and Kramers, J.D. 2010. Re-appraisal of the stratigraphy and determination of new $\mathrm{U}-\mathrm{Pb}$ dates for the Sterkfontein hominin site, South Africa. Journal of Human Evolution, 59:70-86.

Plavcan, J.M. 1993. Catarrhine dental variability and species recognition in the fossil record, p. 239-263. In Kimbel, W.H., Martin, L.B. (eds.), Species, Species Concepts and Primate Evolution. Springer, New York.

Porto, A., de Oliveira, F.B., Shirai, L.T., De Conto, V., and Marroig, G. 2009. The evolution of modularity in the mammalian skull I: morphological integration patterns and magnitudes. Evolutionary Biology, 36:118135.

R Core Team. 2016. R: a language and environment for statistical computing. R Foundation for Statistical Computing, Vienna, Austria. http://www.R-project.org/.

Ravosa, M.J. and Profant, L.P. 2000. Evolutionary morphology of the skull in Old World monkeys, p. 237268. In Whitehead, P.F. and Jolly, C.J. (eds.), Old 
World Monkeys. Cambridge University Press, New York.

Revelle, W. 2015. The psych package - CRAN. https:// cran.r-project.org/web/packages/psych/psych.pdf.

Reynolds, S.C. and Kibii, J.M. 2011. Sterkfontein at 75: review of palaeoenvironments, fauna and archaeology from the hominin site of Sterkfontein (Gauteng Province, South Africa). Palaeontologia Africana, 46:59-88.

Rizk O.T. 2012. Insight into the genetic basis of craniofacial morphological variation in the domestic dog, Canis familiaris. Ph.D. Dissertation, University of California, Berkeley.

Rose, K.D. and Bown, T.M. 1993. Species concepts and species recognition in Eocene primates, p. 299-330. In Kimbel, W., Martin, L. (eds.), Species, Species Concepts and Primate Evolution. Springer, New York.

Roseman, C.C., Kenny-Hunt, J.P., and Cheverud, J.M. 2009. Phenotypic integration without modularity: testing hypotheses about the distribution of pleiotropic quantitative trait loci in a continuous space. Evolutionary Biology, 36:282-291.

Roseman, C.C., Weaver, T.D., and Stringer, C.B. 2011. Do modern humans and Neandertals have different patterns of cranial integration? Journal of Human Evolution, 60:684-693.

Roseman, C.C., Willmore, K.E., Rogers, J., Hildebolt, C., Sadler, B.E., Richtsmeier, J.T., and Cheverud, J.M. 2010. Genetic and environmental contributions to variation in baboon cranial morphology. American Journal of Physical Anthropology, 143:1-12.

Schultz, A.H. 1940. The size of the orbit and of the eye in primates. American Journal of Physical Anthropology, 26:389-408.

Sears, K.E., Finarelli, J.A., Flynn, J.J., and Wyss, A.R. 2008. Estimating body mass in New World "monkeys" (Platyrrhini, Primates), with a consideration of the Miocene platyrrhine, Chilecebus carrascoensis. American Museum Novitates, 1-29.

Sherwood, R.J., Duren, D.L., Demerath, E.W., Czerwinski, S.A., Siervogel, R.M., and Towne, B. 2008a. Quantitative genetics of modern human cranial variation. Journal of Human Evolution, 54:909.

Sherwood, R.J., Duren, D.L., Havill, L.M., Rogers, J., Cox, L.A., Towne, B., and Mahaney, M.C. 2008b. A genomewide linkage scan for quantitative trait loci influencing the craniofacial complex in baboons (Papio hamadryas spp.). Genetics, 180(1):619-628.

Singh, N., Harvati, K., Hublin, J.J., and Klingenberg, C.P. 2012. Morphological evolution through integration: a quantitative study of cranial integration in Homo, Pan, Gorilla and Pongo. Journal of Human Evolution, 62:155-164.

Singleton, M. 2002. Patterns of cranial shape variation in the Papionini (Primates: Cercopithecinae). Journal of Human Evolution, 42:547-578.

Singleton, M. 2012. Postnatal cranial development in papionin primates: an alternative model for hominin evolutionary development. Evolutionary Biology, 39(4):499-520.

Souron, A., Boisserie, J.R., and White, T.D. 2013. A new species of the suid genus Kolpochoerus from Ethiopia. Acta Palaeontologica Polonica, 60:79-96.

Stratford, D., Grab, S., and Pickering, T.R. 2014. The stratigraphy and formation history of fossil-and artefact-bearing sediments in the Milner Hall, Sterkfontein Cave, South Africa: new interpretations and implications for palaeoanthropology and archaeology. Journal of African Earth Sciences, 96:155-167.

Szalay, F.S. and Delson, E. 1979. Evolutionary History of the Primates. Academic Press, New York.

Turner, A. 1990. The evolution of the guild of larger terrestrial carnivores during the Plio-Pleistocene in Africa. Geobios, 23:349-368.

VandeBerg, J.L., Williams-Blangero, S., and Tardif, S.D. (eds.). 2009. The Baboon in Biomedical Research. Springer Science and Business Media, New York.

van Roosmalen, M.G. and van Roosmalen, T. 2003. The description of a new marmoset genus, Callibella (Callitrichinae, Primates), including its molecular phylogenetic status. Neotropical Primates, 11:1-10.

Venables, W.N. and Ripley, B.D. 2002. Modern Applied Statistics with S. Springer, New York.

Vrba, E.S. 1975. Some evidence of chronology and palaeoecology of Sterkfontein, Swartkrans and Kromdraai from the fossil Bovidae. Nature, 254:301-304.

Vrba, E.S. 1982. Biostratigraphy and chronology, based particularly on Bovidae, of southern hominid-associated assemblages: Makapansgat, Sterkfontein, Taung, Kromdraai, Swartkrans; also Elandsfontein (Saldanha), Broken Hill (now Kabwe) and Cave of Hearths. Proceedings of the 1st International Congress of Human Palaeontology, 2:707-752.

Vrba, E.S. 1985. Early hominids in southern Africa: updated observations on chronological and ecological background, p. 195-200. In Tobias P.D. (ed.), Hominid Evolution: Past, Present and Future. Alan R. Liss, New York.

Webster, D. and Webster, M. 2013. Comparative Vertebrate Morphology. Academic Press, New York.

Wickham, H. 2009. ggplot2: Elegant Graphics for Data Analysis. Springer-Verlag, New York.

Williams, F.L., Ackermann, R.R., and Leigh, S.R. 2007. Inferring Plio-Pleistocene southern African biochronology from facial affinities in Parapapio and other fossil papionins. American Journal of Physical Anthropology, 132:163-174.

Williams, F.L. 2013. Dietary reconstruction of Pliocene Parapapio whitei from Makapansgat, South Africa, using dental microwear texture analysis. Folia Primatologica, 85(1):21-37.

Yoder, A.D., Rasoloarison, R.M., Goodman, S.M., Irwin, J.A., Atsalis, S., Ravosa, M.J., and Ganzhorn, J.U. 2000. Remarkable species diversity in Malagasy mouse lemurs (Primates, Microcebus). Proceedings of the National Academy of Sciences, 97:1132511330. 


\section{APPENDIX 1.}

Generalized baboon morphology illustrating measurements taken in this study.

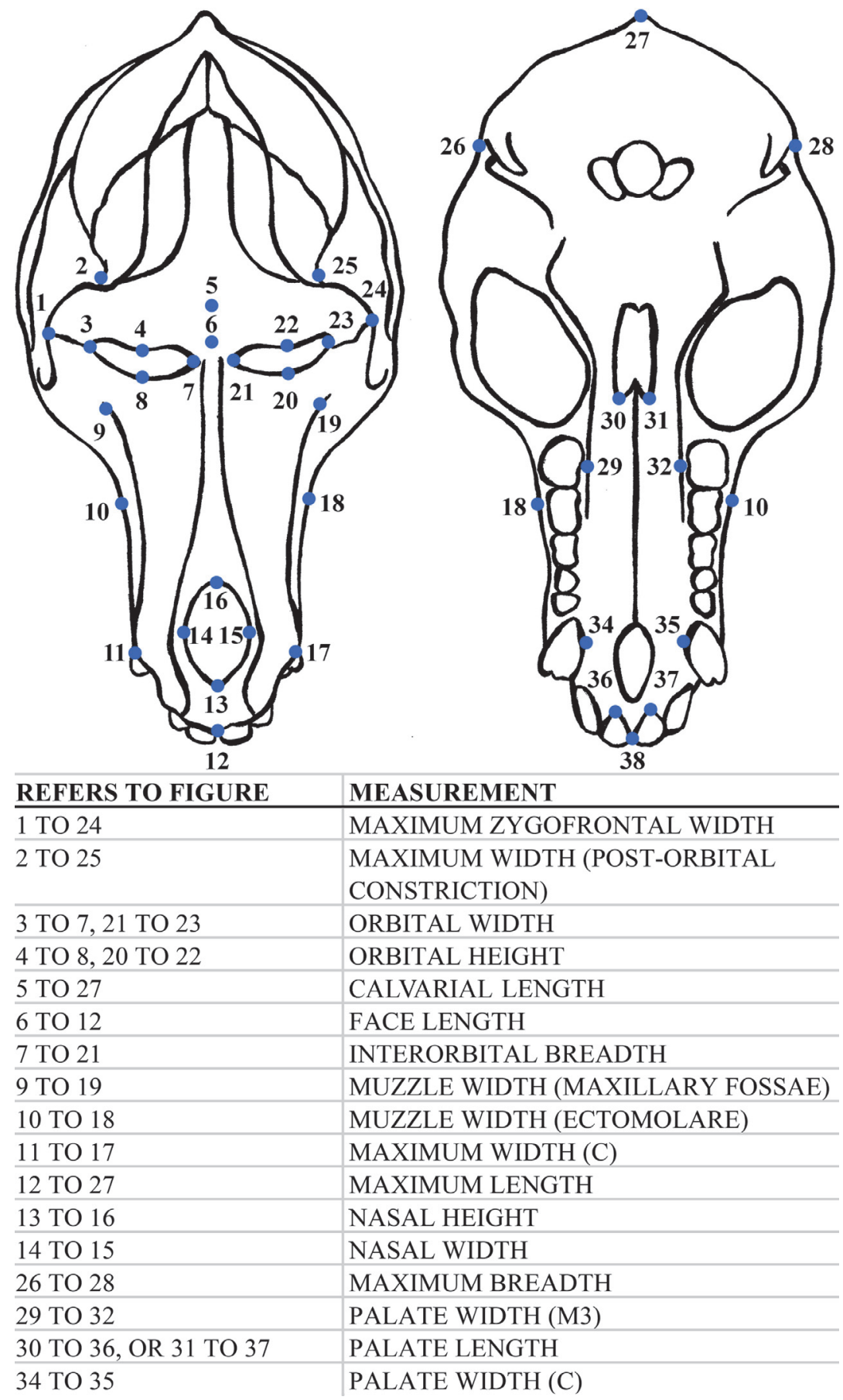




\section{APPENDIX 2.}

Raw data for fossils used in this study. A single set of parentheses indicates that the measurement was estimated with a high degree of confidence, and the values were used in the analyses. A double set of parentheses indicates that the measurement was estimated with a low degree of confidence, and the values were not used in the analyses. (Available as zipped spreadsheet on palaeo-electronica.org/content/2017/1762-fossil-owm-cranial-variation.)

\section{APPENDIX 3.}

Raw data for the extant papionins used in this study. (Available as zipped spreadsheet on palaeo-electronica.org/content/2017/1762-fossil-owm-cranial-variation.)

\section{APPENDIX 4.}

Descriptive statistics for the cranial measurements taken in this study, by fossil species. (Available as zipped spreadsheet on palaeo-electronica.org/content/2017/1762-fossil-owm-cranialvariation.)

\section{APPENDIX 5.}

Full ANOVA detailing genus comparisons for raw cranial measurements across fossil genera. Shaded cells are significant at $p<0.05$. (Available as zipped spreadsheet on palaeo-electronica.org/content/2017/1762-fossil-owm-cranial-variation.)

\section{APPENDIX 6.}

ANOVA detailing extant genus comparisons for geometric mean scaled data for a subset of cranial measurements. Shaded cells are significant at $p<0.05, \mathrm{n}=81$. (Available as zipped spreadsheet on palaeo-electronica.org/content/2017/1762-fossil-owm-cranial-variation.)

\section{APPENDIX 7.}

ANOVA detailing fossil genus comparisons for geometric mean scaled data for a subset of cranial measurements. Shaded cells are significant at $p<0.05, \mathrm{n}=25$. (Available as zipped spreadsheet on palaeo-electronica.org/content/2017/1762-fossil-owm-cranial-variation.)

\section{APPENDIX 8.}

Full correlation matrix detailing fossil correlations and sample size for the 17 geometric mean scaled cranial measurements. Yellow highlighted cells are significant at $p<0.0004$, and grey shaded cells give sample sizes for each measurement pair. (Available as zipped spreadsheet on palaeo-electronica.org/content/2017/1762-fossil-owm-cranial-variation.) 